\title{
Unilateral retinal dysplasia simulating retinoblastoma
}

\author{
Gunjan Saluja, ${ }^{1}$ Neiwete Lomi, ${ }^{2}$ Seema Kashyap ${ }^{3}$
}

'Ophthalmology, Dr. Rajendra Prasad Centre for Ophthalmic Sciences, All India Institute of Medical Sciences, New Delhi, India

20phthalomology, All India Institute of Medical Sciences, New Delhi, India

${ }^{3}$ Ocular Pathology, Dr. Rajendra Prasad Centre for Ophthalmic Sciences, All India Institute of Ophthalmic Sciences, New Delhi, India

Correspondence to

Dr Gunjan Saluja; gunjansaluja2015@gmail.com

Accepted 31 August 2020

Check for updates

(c) BMJ Publishing Group Limited 2020. No commercial re-use. See rights and permissions. Published by BMJ.

To cite: Saluja G, Lomi N, Kashyap S. BMJ Case

Rep 2020;13:e238463.

doi:10.1136/bcr-2020-

238463

\section{DESCRIPTION}

Retinoblastoma is one of the common tumours of childhood, presenting with leucocoria. Some pathologies, however, closely mimic retinoblastoma, one of them being retinal dysplasia. Retinal dysplasia is a rare congenital anomaly that may or may not be associated with systemic abnormalities. Unilateral cases of retinal dysplasia without systemic abnormalities are often diagnosed as retinoblastoma. Herein, we report a typical case of unilateral microphthalmos, which was clinically diagnosed as retinoblastoma but histopathological examination revealed retinal dysplasia

The parents of a 9-month-old child noticed a white reflex in the child's left eye since 6 months of age. They also noticed that the left eye had reduced in size.

The child had a full-term vaginal delivery, with a birth weight of $2000 \mathrm{~g}$.

She was shown to a local practitioner and was referred to our centre for further management. On examination, the child was not following light and objects from the left eye, which also appeared smaller than the right eye. The anterior segment examination was unremarkable. Intraocular pressure with Perkin's tonometer in the right eye was 14 and $10 \mathrm{~mm} \mathrm{Hg}$ in the left eye. The horizontal corneal diameter of the right eye was $11.5 \mathrm{~mm}$ and the left eye was $10 \mathrm{~mm}$. Axial length of the right eye was $22 \mathrm{~mm}$, and the left eye was $18 \mathrm{~mm}$. Fundus examination done under anaesthesia revealed a normal fundus in the right eye; however, fundus details of the left eye were not visible and appeared like a mass filling the vitreous cavity. The systemic examination was unremarkable. Ultrasound B scan revealed the presence of a mass-like lesion with moderate intensity filling the entire vitreous cavity (figure 1). In contrast enhanced MRI, a diffuse heterogeneous mass-like lesion filling the entire left globe, was observed. It appeared hyperintense on both T1 and T2 images, which was suggestive of retinoblastoma. No optic nerve thickening was observed (figure 2).

Thus, a diagnosis of left eye group E retinoblastoma with microphthalmos was made and the child was planned for left eye enucleation with implant.

Histopathology examination revealed the presence of total retinal detachment with retinal degeneration, fibrosis and presence of retinal rosettes. Multiple hemosiderin laden macrophages were also identified, but there was no evidence of retinal tumour or calcification (figure 3 ). Thus, a histological diagnosis of retinal dysplasia was made.

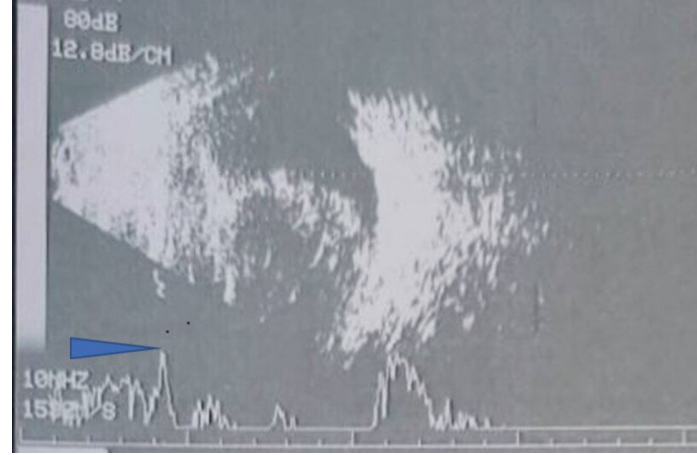

Figure 1 Ultrasound B scan showing mass-like lesion filling the entire globe with moderate-to-high amplitude spikes (as shown by the pointer).

The differential diagnosis of leucocoria include retinal detachment, retinopathy of prematurity, endophthalmitis, Coat's disease, persistent hyperplastic primary vitreous, retinoblastoma and very rarely retinal dysplasia.

Unilateral microphthalmos did raise suspicion of persistent hyperplastic primary vitreous in our case, but it was ruled out due to the absence of a stalk-like structure extending from the optic disc to the lens. Toxocara was ruled out by the normal Toxoplasma, rubella, cytomegalovirus and herpes simplex (TORCH)titres. The suspicion of retinopathy of prematurity was ruled out as the child had a full-term birth and had no history of receiving oxygen supplementation.

Retinal dysplasia is a rare entity, but bilateral retinal dysplasia can be associated with trisomy 13 , Norrie's disease and Walker-Warburg syndrome. ${ }^{1}$

Retinal dysplasia closely mimics retinoblastoma. Sometimes it is impossible to differentiate between the two entities only on the basis of clinical examination, especially in unilateral cases with no other

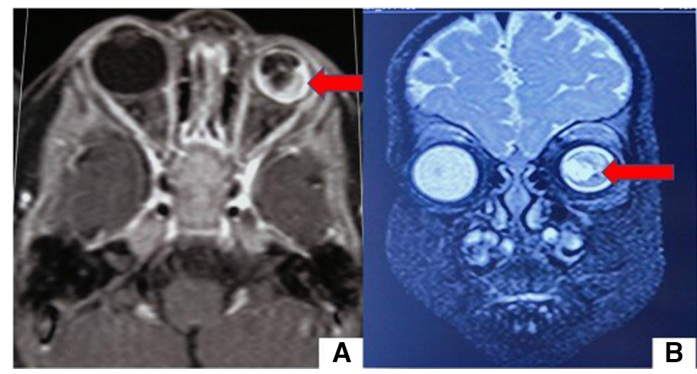

Figure 2 MRIT1 axial view (A) showing an isotenseto-hyperintense lesion and T2 sagittal view (B) showing hyperintense lesion filling the globe (images obtained through telecommunication). 


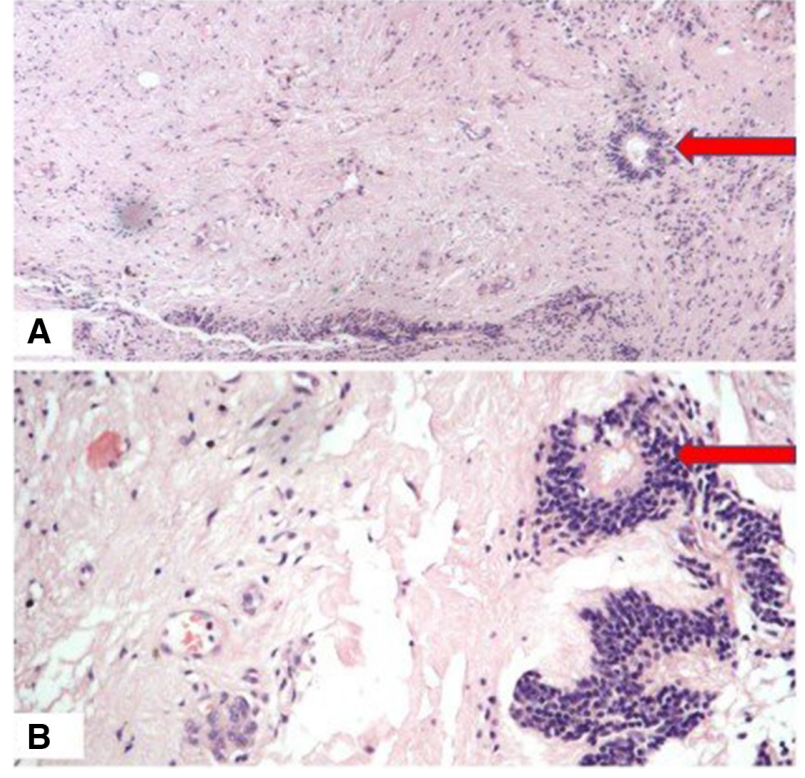

Figure 3 Histopathological examination, (A) Low power view showing fibrosis along with rosettes H\&E stain $\times 40$. (B) High power showing retinal dysplasia in the form of rosettes H\&E stain $\times 100$.

systemic abnormality. Retinal dysplasia results from the separation of retinal pigment epithelium from other layers of the retina during the embryonal stages of development. Further proliferation of glial tissue results in the formation of rosette. Contrastingly, these rosettes do not have atypical malignant cells as found in Flexner-Wintersteiner rosette. ${ }^{2}$

The only difference between retinoblastoma and retinal dysplasia is the presence of calcification in the former. However, Prasanna et al have described the presence of calcification on CT in a case of retinal dysplasia also. ${ }^{3}$

The presence of unilateral retinal dysplasia has been rarely reported. $^{45}$

In a recent case series of two cases, Jakati et al have reported the presence of pseudo hypopyon with leucocoria, which was later diagnosed as retinal dysplasia on histopathological examination. ${ }^{6}$

In our case, it was not possible to diagnose retinal dysplasia in the preoperative period. CT scan was avoided to prevent the undue exposure of radiation. ${ }^{7}$ Although the presence of microphthalmos hinted us about the possibility of retinal dysplasia, the findings on ultrasound B scan and MRI could not be neglected. The case thus reminded us of an important but unusual differential diagnosis of retinoblastoma.

\section{Learning points}

- Retinal dysplasia can closely mimic retinoblastoma and it is impossible to differentiate the two entities clinically.

- Retinal dysplasia typically is present since birth, is associated with microphthalmos and has the absence of calcification.

- The histological examination gives a final diagnosis.

Contributors GS worked up the case. NL critically reviewed the manuscript. SK reviewed the histopathology reports and provided the images.

Funding The authors have not declared a specific grant for this research from any funding agency in the public, commercial or not-for-profit sectors.

Competing interests None declared.

Patient consent for publication Parental/guardian consent obtained.

Provenance and peer review Not commissioned; externally peer reviewed.

\section{REFERENCES}

1 Gerding H, Gullotta F, Kuchelmeister K, et al. Ocular findings in Walker-Warburg syndrome. Child's Nerv Syst 1993;9:418-20.

2 Kaku T, Sasai K, Nagamine Y, et al. Retinal dysplasia--A report of two surgical cases. Acta Pathol Jpn 1975;25:347-53.

3 Prasanna MR, Kwatra KS, Calton N, et al. Retinal dysplasia mimicking retinoblastoma. Indian J Pathol Microbiol 2013;56:64-5.

4 Lambert NG, Mamalis N, Patel BCK, et al. Unilateral retinal dysplasia mimicking retinoblastoma. J Pediatr 2015;167:1449-1449.e1.

5 Biswas S, Paul PC, Chakraborty J, et al. Unilateral retinal dysplasia clinically mimicking retinoblastoma. J Pediatr Ophthalmol Strabismus 2010;47 Online:e1-3.

6 Jakati S, Patel A, Pathengay A, et al. Coincidental retinal dysplasia in patients presenting with pseudohypopyon: a series of two cases. BMJ Case Rep 2020;13:e233922.

7 de Graaf P, Göricke S, Rodjan F, et al. Guidelines for imaging retinoblastoma: imaging principles and MRI standardization. Pediatr Radiol 2012;42:2-14.

Copyright 2020 BMJ Publishing Group. All rights reserved. For permission to reuse any of this content visit

https://www.bmj.com/company/products-services/rights-and-licensing/permissions/

BMJ Case Report Fellows may re-use this article for personal use and teaching without any further permission.

Become a Fellow of BMJ Case Reports today and you can:

- Submit as many cases as you like

- Enjoy fast sympathetic peer review and rapid publication of accepted articles

- Access all the published articles

Re-use any of the published material for personal use and teaching without further permission

Customer Service

If you have any further queries about your subscription, please contact our customer services team on +44 (0) 2071111105 or via email at support@bmj.com.

Visit casereports.bmj.com for more articles like this and to become a Fellow 